\title{
Study of the distribution profile of piperidine alkaloids in various parts of Prosopis juliflora by the application of Direct Analysis in Real Time Mass Spectrometry (DART-MS)
}

\author{
Shachi SingH, ${ }^{*}$ and Sanjay Kumar Verma \\ Center for Biotechnology, Department of Biological Sciences, Birla Institute of Technology and Science, Pilani 333031, \\ India
}

Received 15 August 2012; Accepted 7 October 2012

(C) The Author(s) 2012. This article is published with open access at Springerlink.com

\begin{abstract}
Direct Analysis in Real Time Mass Spectrometry (DART-MS) was applied to identify and study the distribution profile of piperidine alkaloids in different parts of Prosopis juliflora, without isolation and separation of the compounds by standard chromatographic techniques. With the help of DART-MS, chemical fingerprint of raw plant parts were generated, which revealed the presence of piperidine alkaloids in leaf, pod and flower. A comparative study of the distribution pattern, showed variation in the presence and distribution of these alkaloids in various parts of $P$. juliflora. The leaves and pod displayed the largest alkaloid pattern with a total of 12 different alkaloids in each part, whereas only 4 alkaloids were present in flower. Alkaloids: julifloridine, prosopine, prosopinine and prosafrinine were ubiquitously distributed in all the alkaloid rich plant parts. Juliprosopine was pre-eminet alkaloid in leaf, whereas pod and flower displayed copious amounts of julifloridine.
\end{abstract}

Keywords: DART-MS, chemical fingerprint, Prosopis juliflora, piperidine alkaloids, juliprosopine, julifloridine

\section{Introduction}

Prosopis juliflora, a member of family Fabaceae is widespread in Saudi Arabia, United States of America and India. ${ }^{1}$ It is known to contain piperidine alkaloids having medicinal properties. ${ }^{2}$ Many alkaloids such as, juliprosopine, julifloricine, julifloridine, juliprosinine, juliflorinine, ${ }^{3}$ juliprosine, ${ }^{4}$ 3'-oxojuliprosopine, sceojuliprosopinol, 3oxojuliprosine and $3^{\prime}$-oxo-juliprosine ${ }^{5}$ have been isolated from leaves and there in vitro biological activities demonstrated, which include anti-inflammatory, ${ }^{2}$ antibacterial, ${ }^{6,7}$ antifungal, ${ }^{8}$ hemolytic, ${ }^{9}$ allelopathic, ${ }^{10}$ cytotoxic $^{11}$ and antitumoral. ${ }^{12}$ Although the plant is reported to contain pharmacologically active piperidine alkaloids, limited work had been done to study the distribution profile of its metabolite. Consequently, it becomes imperative to analyze different parts of the plant, so that complete pharmacological potential of the plant could be exploited.

Mass spectrometry, one of the indispensable techniques in natural sciences, has been engaged to identify and quantify specified molecules. In the last decade, a wide variety of desorption/ionization methods for mass spectrometry had been developed and subsequently applied to chemical identification. However, the chemical complexity of plant extracts had made mass spectrometric characterization of whole extracts difficult

\footnotetext{
*To whom correspondence should be addressed. E-mail: singhshachi@gmail.com
}

due to the lack of reliable extraction methodologies that can yield optimized extracts with dose-to-dose reliable chemical compositions. ${ }^{13}$ Recently, a new high throughput "ambient" ionization method, Direct Analysis in Real Time Mass Spectrometry (DART-MS), operating in open air have been developed, that ionizes compounds (gas, liquid or solid) directly in their native condition, by passing most steps of the analytical system, ${ }^{14,15}$ such as solvent extraction. DART-MS produces $[\mathrm{M}+\mathrm{H}]^{+}$molecular ions of most compounds, therefore simple and clear mass spectra are obtained even of multi-component samples. DART is coupled to a time of flight (TOF) mass analyzer that provides selectivity and accurate elemental composition assignment through exact mass measurement. Recently many researchers have applied DART technique to directly identify chemical compounds from raw and/or processed plant material, such as, curcumin, which was directly analyzed from turmeric. ${ }^{16}$ It was also employed to determine the molecular formula and structures of toxoid compounds in cell cultures of Taxus wallichian ${ }^{17}$ and alkaloids expressed in the hairy roots of Rauwolfia serpentina. ${ }^{18}$

In the present study, attempts have been made to screen unprocessed plant parts of $P$. juliflora by DART-MS, for the presence of piperidine alkaloids. The research work also aims to assess the variability in distribution of these alkaloids in various plant parts. The confirmation of the structures of the identified compounds was made through high resolution mass measurement (HRMS) and their accurate molecular formula determinations. 


\section{Results and Discussion}

Most of the previous methods applied for characterization of phytochemicals were dependent on tedious and complex solvent extraction processes, followed by identification and quantization of bioactive components by conventional methods such as HPLC, mass techniques, NMR etc. ${ }^{13}$ Apart from problems of extraction methods, identification of the compounds in the extracts, did not gave a clear picture of their relative abundance in the raw plant samples. These problems have been overcome in the present research work with the help of DART-MS technique. No sample preparation was done and different parts (leaf, stem, root, pod and flower) of P. juliflora were analyzed by directly introducing the raw plant material towards the DART source. Compounds were identified by comparing their observed masses with the data available in the literature and their relative abundance was calculated by measuring the intensities of their peaks.

Direct analysis of the leaf, within the mass range of $0-1000$ is shown in Fig. 1a. In the mass spectra, juliprosopine ( $\mathrm{m} / \mathrm{z}$ [M $+\mathrm{H}]^{+}$630.59) was found to be the major alkaloid, with highest peak intensity among the observed alkaloids and hence its relative abundance was assigned to be $100 \%$. A higher resolution of the closely related peaks displayed other major alkaloids with relative abundance between $40-15 \%$, which were: julifloridine $\left(\mathrm{m} / \mathrm{z}[\mathrm{M}+\mathrm{H}]^{+} 300.29\right)$, juliprosine (m/z [M $+\mathrm{H}]^{+}$628.55), prosoflorine $\left(\mathrm{m} / \mathrm{z}[\mathrm{M}+\mathrm{H}]^{+}\right.$627.32), juliprosinine $\left(\mathrm{m} / \mathrm{z}[\mathrm{M}+\mathrm{H}]^{+}\right.$626.55), 3-oxo-juliprosine $(\mathrm{m} / \mathrm{z}$ $[\mathrm{M}+\mathrm{H}]^{+}$625.55), prosopine $\left(\mathrm{m} / \mathrm{z}[\mathrm{M}+\mathrm{H}]^{+} 316.28\right)$ and prosopinine $\left(\mathrm{m} / \mathrm{z}[\mathrm{M}+\mathrm{H}]^{+} 314.28\right)$. Some minor alkaloids observed with relative abundance less than $10 \%$ include: $3^{\prime \prime \prime}-$ oxo-juliprosopine $\left(\mathrm{m} / \mathrm{z}[\mathrm{M}+\mathrm{H}]^{+}\right.$644.56), N-methyl julifloridine $\left(\mathrm{m} / \mathrm{z}[\mathrm{M}+\mathrm{H}]^{+} 313.75\right)$, prosafrinine $\left(\mathrm{m} / \mathrm{z}[\mathrm{M}+\mathrm{H}]^{+}\right.$ 298.26) and projuline $\left(\mathrm{m} / \mathrm{z}[\mathrm{M}+\mathrm{H}]^{+}\right.$421.39) (Table 1$)$.

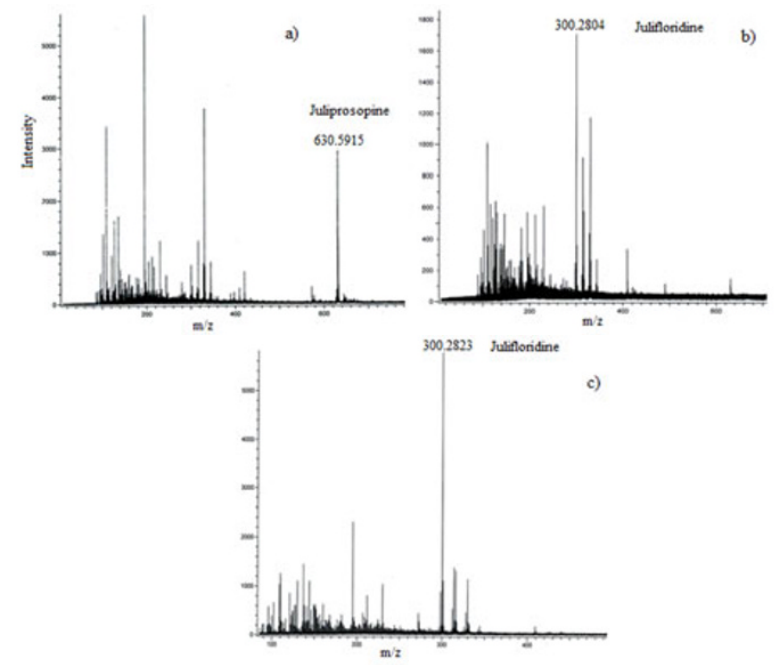

Figure 1. DART-MS of leaf -(a) chemical fingerprint of the compounds present in leaf showing juliprosopine $(\mathrm{m} / \mathrm{z}$ 630.5915) as major alkaloid; (b) chemical fingerprint of the compounds present in pod showing julifloridine $(\mathrm{m} / \mathrm{z}$ 300.2804) as major alkaloid; (c) chemical fingerprint of the compounds present in flower showing julifloridine $(\mathrm{m} / \mathrm{z}$ 300.2823 ) as major alkaloid
Chemical fingerprint analysis of the pod, as shown in Fig. $1 \mathrm{~b}$, revealed julifloridine $\left(\mathrm{m} / \mathrm{z}[\mathrm{M}+\mathrm{H}]^{+} 300.28\right)$ to be the major alkaloid with $100 \%$ relative abundance. Julifloridine was not only the major alkaloid, but was observed to be the most abundant chemical compound present in the pod within the specified mass range in the spectra. A total of 12 alkaloids were identified in pod, most of which were common in leaf. However, there was variation in the distribution of these alkaloids within leaf and pod (Tables 1 and 2). According to the results, the total alkaloid content in pod was shown to be low as compared to leaf. Only two alkaloids, prosopine (52\%) and prosopinine (36.3\%), along with julifloridine were present in high concentrations and most of the other alkaloids in the pod had relative abundance less than $10 \%$, which also include predominant alkaloids of leaf, within the mass range of 625 644.

Table 1. $P$. juliflora leaf DART-MS peak measurements

\begin{tabular}{|c|c|c|c|}
\hline Compound & $\begin{array}{c}\text { Measured } \\
\operatorname{mass}[\mathbf{M}+\mathbf{H}]^{+}\end{array}$ & Mol. formula & $\begin{array}{c}\text { Relative } \\
\text { abundance (\%) }\end{array}$ \\
\hline Juliprosopine & 630.5915 & $\mathrm{C}_{40} \mathrm{H}_{76} \mathrm{~N}_{3} \mathrm{O}_{2}$ & 100 \\
\hline Juliprosine & 628.5555 & $\mathrm{C}_{40} \mathrm{H}_{74} \mathrm{~N}_{3} \mathrm{O}_{2}$ & 36.6 \\
\hline Prosoflorine & 627.3286 & $\mathrm{C}_{40} \mathrm{H}_{73} \mathrm{~N}_{3} \mathrm{O}_{2}$ & 23.3 \\
\hline Juliprosinine & 626.5578 & $\mathrm{C}_{40} \mathrm{H}_{72} \mathrm{~N}_{3} \mathrm{O}_{2}$ & 26 \\
\hline $\begin{array}{l}\text { 3-Oxo- } \\
\text { juliprosine }\end{array}$ & 625.5529 & $\mathrm{C}_{40} \mathrm{H}_{71} \mathrm{~N}_{3} \mathrm{O}_{2}$ & 17 \\
\hline $\begin{array}{l}3^{\prime \prime \prime \prime}-\text {-Oxo- } \\
\text { juliprosopine }\end{array}$ & 644.5636 & $\mathrm{C}_{40} \mathrm{H}_{74} \mathrm{~N}_{3} \mathrm{O}_{3}$ & 3.6 \\
\hline Prosopine & 316.2845 & $\mathrm{C}_{18} \mathrm{H}_{38} \mathrm{NO}_{3}$ & 35 \\
\hline Prosopinine & 314.2816 & $\mathrm{C}_{18} \mathrm{H}_{36} \mathrm{NO}_{3}$ & 35 \\
\hline Julifloridine & 300.2909 & $\mathrm{C}_{18} \mathrm{H}_{38} \mathrm{NO}_{2}$ & 20 \\
\hline Projuline & 421.3983 & $\mathrm{C}_{26} \mathrm{H}_{49} \mathrm{~N}_{2} \mathrm{O}_{2}$ & 4.6 \\
\hline Prosafrinine & 298.2674 & $\mathrm{C}_{18} \mathrm{H}_{36} \mathrm{NO}_{2}$ & 4 \\
\hline $\begin{array}{l}\text { N-methyl } \\
\text { Julifloridine }\end{array}$ & 313.7546 & $\mathrm{C}_{19} \mathrm{H}_{39} \mathrm{NO}_{2}$ & 5 \\
\hline
\end{tabular}

Diversity of alkaloids in flower was low as compared to leaf and pod with a total of 4 piperidine alkaloids identified (Fig. 1c). Julifloridine was present in highest concentration and hence its relative abundance was assigned to be $100 \%$. Along with julifloridine, prosopinine $(24 \%)$, prosopine $(23 \%)$ and prosafrinine $(16.6 \%)$ were identified as major alkaloids (Table 3 ). According to the mass spectra, these alkaloids were also the most abundant chemical compounds present in the flower of P. juliflora.

Table 2. $P$. juliflora pod DART-MS peak measurements

\begin{tabular}{|c|c|c|c|}
\hline Compound & $\begin{array}{l}\text { Measured mass } \\
{[\mathbf{M}+\mathbf{H}]^{+}}\end{array}$ & Mol. formula & $\begin{array}{c}\text { Relative } \\
\text { abundance (\%) }\end{array}$ \\
\hline Juliprosopine & 630.5915 & $\mathrm{C}_{40} \mathrm{H}_{76} \mathrm{~N}_{3} \mathrm{O}_{2}$ & 7 \\
\hline Juliprosine & 628.5555 & $\mathrm{C}_{40} \mathrm{H}_{74} \mathrm{~N}_{3} \mathrm{O}_{2}$ & 3.5 \\
\hline Prosoflorine & 627.3280 & $\mathrm{C}_{40} \mathrm{H}_{73} \mathrm{~N}_{3} \mathrm{O}_{2}$ & 3 \\
\hline Juliprosinine & 626.5576 & $\mathrm{C}_{40} \mathrm{H}_{72} \mathrm{~N}_{3} \mathrm{O}_{2}$ & 2.3 \\
\hline $\begin{array}{l}\text { 3-oxo- } \\
\text { juliprosine }\end{array}$ & 625.5163 & $\mathrm{C}_{40} \mathrm{H}_{71} \mathrm{~N}_{3} \mathrm{O}_{2}$ & 1.6 \\
\hline $\begin{array}{l}3^{\prime \prime \prime \prime}-\text {-Oxo- } \\
\text { juliprosopine }\end{array}$ & 644.5636 & $\mathrm{C}_{40} \mathrm{H}_{74} \mathrm{~N}_{3} \mathrm{O}_{3}$ & 1.4 \\
\hline Prosopinoline & 381.3823 & $\mathrm{C}_{23} \mathrm{H}_{45} \mathrm{~N}_{2} \mathrm{O}$ & 10 \\
\hline Prosopine & 316.2766 & $\mathrm{C}_{18} \mathrm{H}_{38} \mathrm{NO}_{3}$ & 52 \\
\hline Prosopinine & 314.2883 & $\mathrm{C}_{18} \mathrm{H}_{36} \mathrm{NO}_{3}$ & 36.3 \\
\hline Julifloridine & 300.2804 & $\mathrm{C}_{18} \mathrm{H}_{38} \mathrm{NO}_{2}$ & 100 \\
\hline Projuline & 421.3983 & $\mathrm{C}_{26} \mathrm{H}_{49} \mathrm{~N}_{2} \mathrm{O}_{2}$ & 8 \\
\hline Prosafrinine & 298.2674 & $\mathrm{C}_{18} \mathrm{H}_{36} \mathrm{NO}_{2}$ & 12 \\
\hline
\end{tabular}

Nakano et al., 2004, have reported two groups of piperidine alkaloids in $P$. juliflora, first group having two piperidine ring connected by indolizidine ring in the centre of the molecule 
and the second group having one piperidine nucleus, without indolizidine ring. ${ }^{10}$ Juliprosopine, juliprosine, prosoflorine, juliprosinine, 3-oxo-juliprosine and 3"'-oxo-juliprosopine observed in the present work, belong to the first group of alkaloids whereas julifloridine, N-methyl julifloridine, prosopine, prosopinine, Projuline and prosafrinine are assigned to the second group. The above results lead to the conclusion that both groups of alkaloids are present in leaf and pod. However in pod, there seems to be biasness towards abundance of second group of alkaloids as compared to the first group. The metabolic pathway which is responsible for the synthesis of these alkaloids are ambiguous, still it could be concluded that the synthesis machinery of the first group of alkaloids is lacking or present in small amount in pod as compared to the leaf. Chemical fingerprint of flower, showed the presence of only second group of alkaloids and absence of first group. A possible reason could be complete loss of metabolic pathway that leads to their synthesis.

Table 3. $P$. juliflora flower DART-MS peak measurements

\begin{tabular}{lccc}
\hline Compound & $\begin{array}{c}\text { Measured } \\
\text { mass }[\mathbf{M}+\mathbf{H}]^{+}\end{array}$ & Mol. formula & $\begin{array}{c}\text { Relative } \\
\text { abundance (\%) }\end{array}$ \\
\hline Prosopine & 316.2761 & $\mathrm{C}_{18} \mathrm{H}_{37} \mathrm{NO}_{3}$ & 23 \\
Prosopinine & 314.2639 & $\mathrm{C}_{18} \mathrm{H}_{35} \mathrm{NO}_{3}$ & 24 \\
Julifloridine & 300.2823 & $\mathrm{C}_{18} \mathrm{H}_{37} \mathrm{NO}_{2}$ & 100 \\
Prosafrinine & 298.2685 & $\mathrm{C}_{18} \mathrm{H}_{35} \mathrm{NO}_{2}$ & 16.6 \\
\hline
\end{tabular}

The high resolution power of DART-MS allowed the efficient confirmation of detected molecular ions by comparison of the measured molecular mass with the corresponding theoretical molecular mass. Elemental composition of the measured mass, assigned with the help of Mass Center software system was compared with the data available in chemical databases (Dictionary of Natural Products, Chapman \& Hall) and was found to be identical.

The mass spectra, thus obtained displayed piperidine alkaloids in leaf, pod and flower, whereas, other tested parts of the plant (stem and root) were found to be devoid of these alkaloids. Variations were observed in the presence and distribution of the alkaloids between leaf, pod and flower. These results are in consistent with the findings of other researchers, who have reported a high degree of qualitative and quantitative variability of piperidine alkaloids among tissues within species. ${ }^{19,20}$ The abundance and diversity of alkaloids in aerial parts of the plant may be attributed to the protective mechanism of the plant against animals and pathogens. $^{21}$

Prosopine and prosopinine alkaloids, had been reported in $P$. africana, ${ }^{22}$ however, the analysis conducted by DART-MS confirmed the presence of these alkaloids in $P$. juliflora. Therefore, in order to verify these alkaloids and test the efficacy of DART results, they were subjected to LC/MS/MS analysis for study of their fragmentation pattern.

The molecular ion for prosopinine at $\mathrm{m} / \mathrm{z}[\mathrm{M}+\mathrm{H}]^{+} 314$, lead to characteristic product ions at $\mathrm{m} / \mathrm{z} 296,282,214,184$, 158, 144 and 131 (Fig. 2) and for Prosopine $\left(\mathrm{m} / \mathrm{z}[\mathrm{M}+\mathrm{H}]^{+}\right.$ 316) fragments were observed at $\mathrm{m} / \mathrm{z} 300,298,242,214158$ and 131 (Fig. 3). On the basis of the fragmentation pattern, theoretically generated, the product ion profile derived from precursor ion of $\mathrm{m} / \mathrm{z} 314$ and 316 was compared. Since these compounds are commercially unavailable, there fragmentation pattern was elucidated with the help of software program

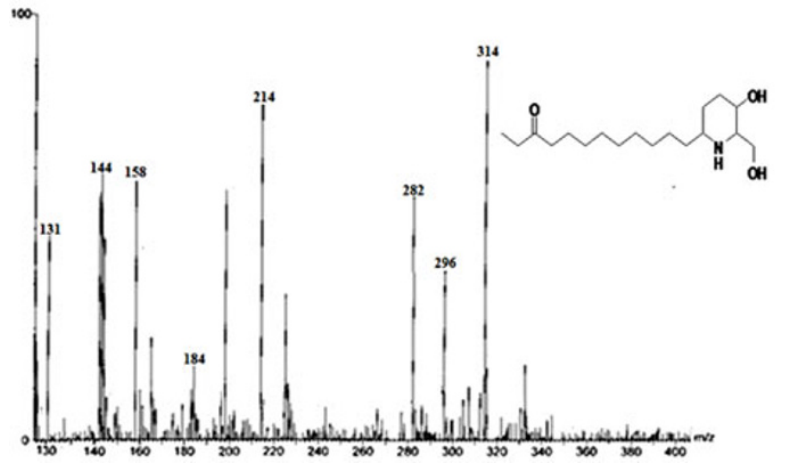

Figure 2. LC/MS/MS spectrum of prosopinine showing fragmented ions peak

(chemdraw).

In the mass spectra of prosopinine $(\mathrm{m} / \mathrm{z} 314)$, the ion at $\mathrm{m} / \mathrm{z}$ 296 was formed by loss of water from the molecular ion and the ion at $\mathrm{m} / \mathrm{z} 282$, by loss of $\mathrm{CH}_{3} \mathrm{OH}$ group from the heterocyclic ring. Fragment at $\mathrm{m} / \mathrm{z} 184$ aroused by removal of 2-hydroxymethyl piperidin-3-ol ring from the hydrocarbon chain and peak representing $\mathrm{m} / \mathrm{z} 131$ corresponds to 2-hydroxymethyl piperidin-3-ol ring. The ions at $\mathrm{m} / \mathrm{z} 144,158$, 214 , were formed by cleavage of hydrocarbon chains at different locations

For prosopine alkaloids (m/z 316), the ion at $\mathrm{m} / \mathrm{z} 300$ was formed by loss of a methyl group from the parent ion and $\mathrm{m} / \mathrm{z}$ 298 fragment was formed by loss of water. Fragment at $\mathrm{m} / \mathrm{z}$ 131 was formed by formation of 2-hydroxymethyl piperidin-3ol ring. The ions at m/z 242, 214 and 158 were formed by cleavage of hydrocarbon chain. The product ion spectra of both the alkaloids were found to match with the theoretically generated fragments, confirming the presence of these alkaloids in $P$. juliflora.

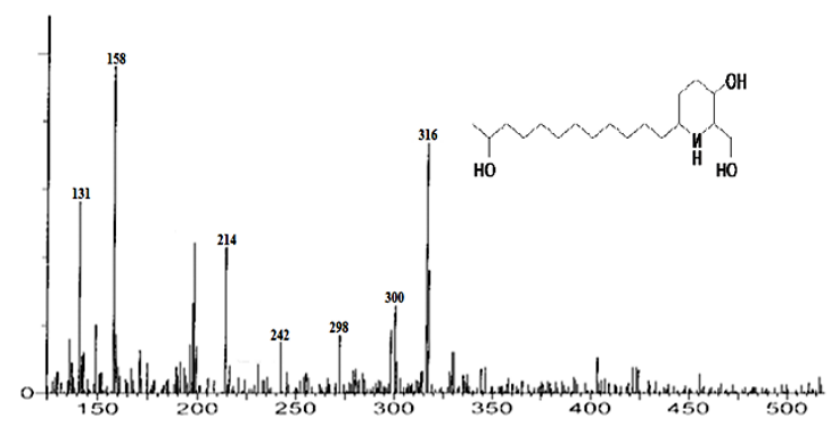

Figure 3. LC/MS/MS spectrum of prosopine showing fragmented ions peak

\section{Experimental Section}

Plant Material. Plant material (leaf, pod, flower, root and stem) of Prosopis juliflora were collected from the Shekhawati regions of Rajasthan, India and identified with the help of "Flora of Rajasthan". ${ }^{23}$ A voucher specimen was deposited in Dungar College herbarium, Rajasthan, India (DCH5092). Samples were thoroughly washed with tap water and distilled water in order to remove any foreign particle attached to its surface and kept in oven to dry at a temperature below $50{ }^{\circ} \mathrm{C}$. 
The alkaloidal extract was obtained by the method described by Ott Longoni et al. ${ }^{24}$ which is based on an acid/basic extraction process leading to the production of the alkaloid rich fraction (ARF).

DART-MS Analysis. The DART-MS was recorded on a JEOL-AccuTOF JMS-T100LC (Jeol, Tokyo, Japan) Mass spectrometer having a DART (Direct Analysis in Real Time) source coupled with an AccuTOF (Accurate Time of Flight) mass detector. Samples were subjected to DART source and dry Helium was used with $4 \mathrm{~L} / \mathrm{min}$ for ionization at $350{ }^{\circ} \mathrm{C}$. For the mass spectrometer, the following settings were loaded: orifice 1 set to $28 \mathrm{~V}$, ring lens voltage set to $13 \mathrm{~V}$, Ion guide RF Volt was set at $1000 \mathrm{~V}$, spectra recording interval was $0.4 \mathrm{~s}$ and acquired $\mathrm{m} / \mathrm{z}$ range was 10.0 to 1050.0 A solution of (poly ethylene glycol) PEG600 was used for calibration. The same calibrant was also introduced at the end of each sample analysis to perform mass drift compensation. The sample was positioned in the gap between the DART source and mass spectrometer for measurements and was introduced into the DART He plasma using the closed end of a borosilicate glass melting point capillary tube until a signal was achieved in the total-ion chromatogram (TIC). The next sample was introduced when the TIC returned to baseline levels. Samples were analyzed in positive ion mode $[\mathrm{M}+\mathrm{H}]^{+}$. HRMS was done and candidate molecular formulae were identified using elemental composition and isotope matching programs of the Mass Center software.

LC-ESIMS/MS Analysis. The Liquid Chromatography Electrospray Mass Spectrometry was performed on Thermo Finnigan LCQ Advantage max ion trap mass spectrometer having Finnigan Surveyor HPLC system connected to it. HPLC system contained Surveyor autosampler and Surveyor PDA detector. The column was thermo ODS-2, 250 X 4.6, 5 $\mu \mathrm{m}$. The elution gradient was carried out with binary solvent system consisting of acetonitrile (solvent A) and methanol (solvent B) at a constant flow-rate of $0.8 \mathrm{~mL} / \mathrm{min}$. Linear gradient profile with the following proportions $(\mathrm{v} / \mathrm{v})$ of solvent A and B was applied: $(90,10),(80,20),(70,30),(50,50),(40$, $60),(20,80),(0,100)$ with $5 \mathrm{~min}$ for re-equilibration. Injection volume was $20 \mu \mathrm{L}$ and data was collected in the range of $210-400 \mathrm{~nm}$. After the separation was achieved, separated compounds were introduced into the ESI source. Capillary temperature was kept up to $275^{\circ} \mathrm{C}$ and spray voltage $4.5 \mathrm{kV}$. The mass spectra were scanned in the range 100-1500 $\mathrm{Da}$ and the maximum ion injection time was set $50 \mathrm{nS}$. All the analyses were performed in positive ion mode.

Calculation of Relative Abundance. Alkaloid with highest peak intensity in the spectra was assigned $100 \%$ and relative abundance of all other alkaloids were calculated by comparing the intensity of their peaks (in percentage) with the highest peak signal.

\section{Electronic Supplementary Material}

Supplementary material is available in the online version of this article at http://dx.doi.org/ 10.1007/s13659-012-0069-1 and is accessible for authorized users.

\section{Acknowledgments}

We acknowledge Birla Institute of Technology and Science for providing laboratory facilities and Central Drug Research Institute, Lucknow, for performing DART and LC-MS/MS analysis. Shachi Singh acknowledges the CSIR for fund support in the form of Senior Research Fellowship.

Open Access This article is distributed under the terms of the Creative Commons Attribution License which permits any use, distribution, and reproduction in any medium, provided the original author(s) and source are credited.

\section{References}

[1] Al-Humaid, A. I.; Warrag, O. A. J. Arid Environ. 1998, 38, 237243.

[2] Ahmad, V. U.; Sultana, A.; Qazi, S. J. Nat. Prod. 1989, 5, 497501.

[3] Ahmad, V. U. ; Basha, A.; Haque, W. Z. Naturforsch. 1978, 33, 347-348.

[4] Daetwyler, P.; Ott-Longoni, R.; Schöpp, E.; Hesse, M. Helvet. Chim. Acta. 1981, 64, 1959-1963

[5] Nakano, H.; Nakajima, E.; Hiradate, H.; Fujii, Y.; Yamada, K.; Shigemori, H.; Hasegawa, A. Phytochemstry 2004, 65, 587-591.

[6] Shankarmurthy, P.; Siddiqui, S. J. Sci. Ind. Res. 1988, 7, 188-192.

[7] Singh, S.; Swapnil; Verma, S. K. Inter. J. Pharma. Sci. Res. 2011, $2,114-120$.

[8] Kanthasamy, A.; Subramanian, S.; Govindasamy, S. Indian Drugs 1989, 26, 390-394.

[9] Kandasamy, A.; William, S.; Govindasamy, S. Cur. Sci. 1989, 58, 142-144.

[10] Nakano, H.; Nakajima, E.; Hiradate, S.; Fujii, Y.; Yamada, K.; Shigemori, H.; Hasegawa, K. Plant Growth Regul. 2004, 44, 207-210.

[11] Silva, A. M. M.; Silva, A. R.; Pinheiro, A. M.; Freitas, S. R. V. B.; Silva, V. D. A.; Souza, C. S.; Hughes, J. B.; El-Bacha, R. S.; Costa, M. F. D.; Velozo, E. S.; Tardy, M.; Costa, S. L. Toxicon 2007, 49, 601-614.

[12] Batatinha, M. J. M. [Doctoral Thesis]. Hannover: Veterinary Medicine University, 1997.

[13] Roschek, B. J.; Fink, R. C.; McMichael, M. D.; Alberte, R. S. Phytochemstry 2009, 70, 1255-1261.

[14] Cody, R. B.; Laramee, J. A.; Durst, H. D. Anal. Chem. 2005, 77, 2297-2302.

[15] Kubec, R.; Cody, R. B.; Dane, A. J.; Musah, R. A.; Schraml, J.; Vattekkatte, A.; Block, E. J. Agric. Food Chem. 2010, 58, 11211128.

[16] Kim, H. J.; Jang, Y. P. Phytochem. Anal. 2009, 20, 372-377.

[17] Banerjee, S.; Madhusudanan, K. P.; Khanuja, S. P.; Chattopadhyay, S. K. Biomed. Chromatogr. 2008, 22, 250-253.

[18] Madhusudanan, K. P.; Banerjee, S.; Khanuja, S. P.; Chattopadhyay, S. K. Biomed. Chromatogr. 2008, 22, 596-600.

[19] Stermitz, F. R.;. Tawara, J. N.; Boeckl, M.; Pomeroy, M.; Foderaro, T. A.; Todd, F. G. Phytochemstry 1994, 35, 951-953.

[20] Todd, F. G.; Stermitz, F. R.; Blohkin, A. V. Phytochemstry 1995, $40,401-406$.

[21] Elisabetsky, E.; Costa-Campos, L. Alternat. Med. 2006, 3, 3948.

[22] Ratle, G.; Monseur, X. ; Das, B.C.; Yassi, J.; Khuong-Huu, Q. Goutarel, R. Bulletin de la Société chimique de France 1966, 9, 2945-2947.

[23] Shetty, B. V.; Singh, V. Flora of rajasthan, Vol 3, Botanical Survey of India, Calcutta, 1993.

[24] Ott-Longoni, R.; Viswanathan, N.; Hesse, M. Helvet. Chim. Acta. 1980, 63, 2119-2129. 